\title{
La Santa Sede y los candidatos al trono de España en la estrategia propagandística de la Guerra de Sucesión*
}

\section{David GONZÁLEZ CRUZ}

Catedrático de Universidad, Área de Historia Moderna

Universidad de Huelva

david@uhu.es

\section{INTRODUCCIÓN}

Este trabajo de investigación, al analizar el lugar ocupado por la Santa Sede en el diseño publicitario de la Guerra de Sucesión española aborda una temática con repercusiones en Roma y en el conjunto de la Monarquía Hispánica que requiere una perspectiva global, puesto que los hechos acontecidos en la sede del Papado pueden explicar las reacciones y actitudes en otros lugares y viceversa, de manera que si se investigaran los diferentes espacios como si estuvieran desconectados originaría que algunas cuestiones propagandísticas que se encontraban vinculadas pudieran pasar desapercibidas; por supuesto, esta doble perspectiva tiene su complejidad, si bien merece la pena afrontarla y atenderla con el fin de enriquecer los resultados esperados. Con este objetivo y con el espíritu de avanzar en el conocimiento integral del sistema publicitario durante la crisis sucesoria ${ }^{1}$, sin las limitaciones que a veces

* Esta investigación ha sido realizada en el marco del proyecto HAR2010-15141, financiado por el Ministerio de Economía y Competitividad del Gobierno de España y por FEDER de la Unión Europea.

1 El análisis de la propaganda, información y opinión pública está siendo objeto de diferentes investigaciones de interés para el conocimiento de la historia de la comunicación en la Edad Moderna; en concreto, pueden reseñarse como ejemplo: Roger CHARTIER y Carmen EsPEJO, $L a$ aparición del periodismo en Europa. Comunicación y propaganda en el Barroco, Marcial Pons, Madrid, 2012, 281 pp. Fernando BOUZA, Papeles y opinión. Políticas de publicación en el Siglo de Oro, CSIC, Madrid, 2008, 230 pp. Hélö̈se Hermant, Guerres de plumes. Publicité et cultures politiques dans 
imponen las parcelaciones territoriales, se ha realizado un cruzamiento de numerosas fuentes consultadas procedentes de diversos archivos y bibliotecas nacionales e internacionales donde se hallan conservados los documentos manuscritos e impresos que son testimonio de los recursos propagandísticos utilizados en relación con el papel desempeñado por la Santa Sede durante la Guerra de Sucesión española²; entre ellos pueden citarse el Archivio Segreto Vaticano, el Archivo de la Embajada de España cerca de la Santa Sede, el Archivo General de Indias, el Archivo Histórico Nacional, la Real Academia de la Historia, el Archivo General del Ministerio de Asuntos Exteriores de España, la Bibliothèque Nationale France, el Archivo del Ministère des Affaires Etrangères, el Archivo General de la Nación de México, la Biblioteca Nacional de España (sección de manuscritos), la Real Biblioteca y algunas bibliotecas universitarias españolas. A todo ello se sumaría la prensa periódica editada a principios del siglo XVIII, las relaciones de sucesos y diarios, los impresos publicitarios, la literatura religiosa, las crónicas, y las obras historiográficas elaboradas por autores contemporáneos a los hechos analizados, los breves papales y los decretos reales, entre otras fuentes.

\section{ROMA COMO ESPACIO TRANSMISOR Y MEDIO PUBLICITARIO DE LA CONTIENDA DINÁSTICA}

Una vez analizada toda esta base documental se aprecia que la ciudad de Roma se transformó en un escenario relevante en la disputa propagandística entre los dos aspirantes a la Corona de España, pues de forma semejante a como sucedía en los reinos de la Monarquía Hispánica se mantuvo un incesante es-

l'Espagne dans la fin du XVIIe siècle, Casa de Velázquez, Madrid, 2012, 582 pp. Carmen EsPEJO CALA, Propaganda impresa y construcción del estado moderno y contemporáneo, Alfar, Sevilla, 2000, 178 pp. Brendan DOOLEY y Sabrina BARON (eds.), The politics of information in Early Modern Europe, Routledge, Londres-Nueva York, 2001, 320 pp. Joad RAYMOND, Pamphlets and pamphleteering in Early Modern Britain, Cambridge University Press, Cambridge, 2003, 426 pp. Mario INFELISE, Prima dei giornali. Alle origini della pubblica informazione, Laterza, Roma-Bari, 2002, 232 pp. Joop W. KoOpMans (ed.), News and politics in Early Modern Europe (1500-1800), Peeters, Louven, 2005, 269 pp.

2 Entre los estudios publicados sobre el Pontificado de Albani pueden consultarse: Stefano ANDRETTA, Clemente XI, Enciclopedia dei Papi, III, Istituto della Enciclopedia Italiana, Roma, 2000, 394-403 y 405-420. Lucien CEYSSENS, L'auteur de la Constitution, le Pape Clement XI (1649-1721), Bulletin de l'Institut historique belge de Rome, 53-54 (1983-1984), pp. 253-304. Además, se recoge una amplia bibliografía sobre este periodo en David MARTÍN MARCOS, Ideología e historiografía en torno al papel del Papado en la Guerra de Sucesión española, en Anuario de Historia de la Iglesia, 19 (2010), pp. 361-372. 
fuerzo publicitario por parte de los partidarios de Felipe de Anjou y de Carlos de Austria durante la crisis sucesoria de principios del Setecientos. Desde luego, este segundo teatro de operaciones en la estrategia diseñada para la justificación y puesta en práctica de los correspondientes derechos dinásticos resultaba lógico si se tiene en cuenta que siendo la Santa Sede un referente moral para el mundo católico cobraba un indudable protagonismo en las campañas informativas de contenido religioso confeccionadas por ambos bandos en un conflicto que de forma interesada los contendientes -especialmente los borbónicos- le dieron el calificativo de «guerra de religión» ${ }^{3}$. Sobre este marco es indudable que el Sumo Pontífice y el Sacro Colegio Cardenalicio se constituyeron en objetivos de la propaganda política como fórmula para incidir en sus respectivos posicionamientos con respecto a los candidatos al Trono de España; de igual modo, Roma se había convertido, desde siglos precedentes, en un espacio privilegiado para esparcir noticias y mensajes por toda Italia, por las cortes extranjeras y por los propios reinos que integraban la Monarquía hispana como consecuencia de ser un lugar de encuentro y comunicación de la diplomacia internacional y un centro neurálgico del trasiego de los clérigos seculares y de los miembros de las órdenes religiosas repartidas por los diferentes territorios del Imperio español ${ }^{4}$. En este sentido, no se puede olvidar el incuestionable papel que desempeñó el estamento eclesiástico en la difusión de las dos candidaturas mediante los discursos y consejos irradiados desde el púlpito, el confesionario o, en su caso, a través de textos impresos. Por todo ello, la ciudad eterna había logrado situarse como altavoz destacado, de efectos multiplicadores, de todas aquellas informaciones relacionadas con la querella sucesoria y con los enfrentamientos bélicos entre las potencias europeas ${ }^{5}$; precisamente, sobre la capacidad expansiva de las noticias divulgadas en la capital de la Cristiandad, así como sobre los posibles

3 Puede verse la utilización del mencionado calificativo en David GONZÁLEZ CrUZ, Guerra de religión entre príncipes católicos. El discurso del cambio dinástico en España y América, 1700-1714, Ministerio de Defensa, Madrid, 2002, 313 pp.

4 En torno a la reconstrucción de la presencia de los clérigos españoles en Roma durante la Edad Moderna resultan significativas, entre otras obras: Thomas J. DANDELET, La Roma española (1500-1700), Barcelona, Crítica, 2002, pp. 176-187. Alessandra ANSELMI, Le chiese spagnole nella Roma del Seicento e del Settecento, Gangemi Editore, Roma 2012, 96 pp.

5 Las investigaciones realizadas respecto a los siglos XVI y XVII han demostrado que la ciudad de Roma fue también un espacio en el que se visualizaban los conflictos y tensiones existentes entre las diferentes nacionalidades de la Europa católica. Vid. Maria Antonietta VIsCEGLIA, Convergencias y conflictos. La Monarquía Católica y la Santa Sede (siglos XV-XVIII), en Studia Histórica, Historia Moderna, 26 (2004), pp. 186-187. Thomas J. DANDELET, op. cit., 316 pp. 
perjuicios causados por la comunicación de las derrotas resultaba muy sugerente la expresión alusiva al «veneno ${ }^{6}$ que se introducía desde Roma por los reinos de la Monarquía y que empleaba el Duque de Uceda -Embajador de Felipe V ante la Santa Sede- en una carta enviada al Gobernador de Milán el 12 de junio de 1706:

... publicaron los parciales tudescos una victoria por Milord Malboroug donde suponían 17 mil muertos de nuestra parte 7 mil prisioneros, todo el vagage y artillería con las plazas de Lobaina, Bruselas y Amberes (...), que no sean considerables los efectos de esta victoria, la qual tú sabrás mejor que nosotros: por lo que te suplico me digas lo que hubieses entendido de ella sirviendo mucho aquí (en Roma) donde todo se convierte en veneno para introduzirle por los miembros de la Monarchia ${ }^{7}$.

En este contexto, sin entrar en la veracidad o no de acontecimientos bélicos concretos, la práctica de difundir noticias en Roma sobre los enfrentamientos armados ${ }^{8}$, al igual que sucedía en la Península Ibérica y en otros países europeos, se insertaba en la estrategia de los dos contendientes de confeccionar discursos creíbles que incrementaran sus adeptos y desactivaran la moral de los adversarios, así como de sus posibles apoyos, entre otros objetivos, aunque para ello fuera necesario que el relato de los hechos se apartara con frecuencia de la realidad. Así lo que en alguna otra ocasión se ha denominado «publicística de la verosimilitud $»^{9}$, se nutría en ocasiones, pero con cierta reiteración, de falsas

6 Esta expresión ha sido desarrollada como concepto publicístico en el marco de las interrelaciones que se daban entre la propaganda y las facciones políticas en la esfera pública de Francia durante el siglo XVII. Jeffrey K. SAWYER, Printed Poison: pamphlet propaganda, faction politics, and the public sphere in early seventeenth-century France, University of California Press, Berkeley and Los Angeles, 1990.

7 Bibliothèque Nationale France (BNF), Manuscrits Occidentaux, Lorraine, vol. 856, fols. 285r-287r.

8 Este procedimiento de divulgación de informaciones sobre los sucesos militares acontecidos se aprecia con reiteración en los testimonios ofrecidos por los contemporáneos romanos; no en vano, en el Diario di Roma, se observa que en cuatro ocasiones, al menos, durante los meses de enero y febrero de 1711, se hacía mención a la labor publicitaria realizada por los partidarios de Felipe V con el objetivo de que se conociese el dominio de las tropas borbónicas sobre la ciudad de Girona. Precisamente, en una de ellas, la correspondiente al 20 de enero de ese año, afirmaba su autor: «Hanno li galllispani sparsa voce che li 3 del corrente si fosse resa all'essercito francese commandato dal duca di Novaglies la Piazza importantissima di Girona». De igual modo, se dejaba constancia de este éxito bélico el 21 de febrero en estos términos: «Li gallispani hanno sparsa voce che il re Filippo V si sia reso padrone di Girona». Francesco VALESIO, Diario di Roma, vol. IV. Milán, Longanesi, 1978, pp. 425, 426, 434 y 439.

9 David GONZÁlez CRUZ, Propaganda e información en tiempos de guerra. España y América (17001714), Sílex, Madrid, 2009, pp. 157-174. 
noticias ${ }^{10} \mathrm{y}$ de acusaciones mutuas de acudir al engaño, tal como lo hacía el Duque de Uceda con el austriaco Monseñor Cautniz, a quien describía en una carta redactada el 29 de mayo de 1706 como un agente austracista que se dedicaba a tergiversar el resultado de las operaciones militares generando una notable confusión entre los diplomáticos residentes en la ciudad y, como es lógico, entre los propios romanos:

Aquí nos hallamos en la mayor confusión del Mundo porque Monseñor Caunitz después de haver llegado la posta de Génova ha esparzido que de allí se le avisaba que el Rey no solo había levantado el sitio de Barzelona sino es que havía pasado a Perpiñán abandonando bagage y artillería, y como este Prelado siempre es inverídico en sus noticias, debemos presumir lo será también en esta especialmente $(. . .)^{11}$.

En este sentido, el procedimiento de contrastar informaciones en la sede central del mundo católico se presentaba como una fórmula imprescindible para salvar las falsedades que circulaban como fruto de las campañas publicitarias organizadas por los partidarios de Felipe de Anjou y de Carlos de Austria para influir en las decisiones de Clemente XI y del Sacro Colegio Cardenalicio; no en vano, los propios autores de los impresos propagandísticos reconocían la utilización de la táctica de divulgar noticias satisfactorias para el príncipe al que servían como instrumento para cambiar o, en su caso, reforzar la posición del Papado respecto a cada uno de los aspirantes a la Corona de España. De ello se hacía eco, entre otros textos publicados, una relación de sucesos fechada en febrero de 1711, que aludía a las batallas de Brihuega y Villaviciosa acontecidas en diciembre del año anterior y a las repercusiones inmediatas originadas en la Corte de Roma por la comunicación de las victorias de unos y las derrotas de los otros:

Las de Roma de 28 de Diciembre, avisan que el partido Austriaco en aquella Corte estaba tan dominante que supeditaba a todos y muy esperanzado de conseguir quanto deseaba, pero que el arribo de un Expresso despachado por N.G.M. Felipe V a Mons. Molines, Auditor de Rota, con la noticia de aver entrado en la Corte de Madrid, se avía suspendido todas las mañosas pretensiones de los Tudescos; y al arribo de otros dos Expressos con las noticias de lo de Briguega y feliz batalla de Villaviciosa se avía mudado totalmente el Teatro; pues todos los Cardenales, Príncipes y Prelados y de-

10 A esta práctica de divulgar información ajena a la realidad se refería Gravina, en un texto escrito en Roma el 16 de mayo de 1711, cuando aludía a la «lujuria de inventar» («tanta è la libídine d'inventare»). Gianvincenzo GRAVINA (edición de Antonio Sarubbi), Curia romana e Regno di Napoli. Cronache politiche e religiose nelle lettere a Francesco Pignatelli (1690-1712), Guida Editori di Mario e Giuseppe Guida, Napoli, 1972, p. 352.

11 BNF, Manuscrits Occidentaux, Lorraine, vol. 856, fols. 268r-269v. 
más Nobleza Romana avían pasado al Palacio de Monseñor Molines, a congratularse de los felizes sucessos de Felipe V y que las cosas tenían tal positura que se esperaba muy en breve el amigable ajuste de las dos Coronas con su Santidad... ${ }^{12}$.

Desde luego, este flujo y reflujo de la información y de la propaganda entre la sede del Papado y los diferentes territorios hispánicos, manifiestan los efectos que esta circulación de noticias verídicas o simuladas tenían en el discurrir de la contienda bélica y sucesoria.

\section{LA LABOR DIVULGATIVA Y PROPAGANDÍSTICA DE JOSÉ MOLINES}

Si los desenlaces de las batallas de Brihuega y Villaviciosa mencionadas anteriormente y la difusión de otros éxitos bélicos como la toma de Girona por las tropas borbónicas ${ }^{13}$, propiciaron que la actividad informativa desarrollada por José Molines en la Santa Sede en favor de la causa felipista avanzara positivamente a partir de 1711, no es menos cierto que su tarea previa en este sentido por parecidas razones militares -relacionadas en esta ocasión con la presión ejercida por las tropas alemanas sobre los Estados Pontificios- había encontrado la indiferencia de la mayoría de la Curia una vez que Carlos de Austria fue reconocido como Rey de España por el Santo Padre. Precisamente unos días después de la firma de las capitulaciones que incluía el mencionado reconocimiento, el 24 de enero de 1709, el auditor Molines manifestaba a Félix de la Cruz Haedo -Secretario del Consejo de Indias- su impotencia para que prosperase su insistente tarea de divulgar los derechos dinásticos de Felipe de Anjou, pues afirmaba -atendiendo a su propia expresión- que «todo es predicar al desierto» ${ }^{14}$; a este respecto, dentro de un tono justificativo relativo al escaso fruto obtenido por sus esfuerzos publicitarios registraba unas palabras que atribuía a Su Santidad, quien -según él- le había respondido que «lo sentía mucho» y que no lo había podido evitar a causa de «las violencias» que había padecido de los alemanes. No obstante, su capacidad persuasiva repercutió en la actitud del Sumo Pontífice, a pesar de lo que él mismo hubiera podido declarar, sobre todo si se tiene en cuenta que el marqués de Prié -Plenipotenciario Imperial en las negociaciones con la Santa Sede- dejaba constancia, en una carta remitida al emperador José I en diciembre

12 Noticias de oy 21 de febrero de 1711, p. 89 (BIBLIOTECA GENERAL DE LA UNIVERSIDAD DE SEVILLA [BUS], Fondo Antiguo, Estante 110, n 38).

13 Gianvincenzo GRAVINA, Curia romana..., p. 348.

14 ArChivo Histórico NACIONAL (AHN), Estado, legajo 4813. 
de 1708, de que las visitas de Molines producían una cierta angustia al Papa que le conducía a desear un acuerdo que complaciese a la Casa de Austria sin romper con la dinastía borbónica ${ }^{15}$. Con todo, el representante de Felipe $\mathrm{V}$ no disculpó a Clemente XI de la responsabilidad de su decisión final; por el contrario, consideraba en la carta enviada al citado Secretario del Consejo que la declaración del Archiduque como Rey habría podido remediarla «si hubiese consultado y creído a los hombres de bien y no a los pícaros y enemigos nuestros» ${ }^{16}$.

Sin duda, Molines se había destacado por servir con pasión y entusiasmo a Felipe de Anjou, hasta el punto de afirmar que lo defendía en Roma «contra todo el Infierno», dedicándose de manera constante a informar al Papa, a los cardenales y a los ministros respecto a los motivos alegados por los partidarios de Carlos de Austria para que se le considerara Rey Católico. El mismo auditor confesaba a Félix de la Cruz Haedo haberse sobrepuesto a unos dolores de costado y a fiebres nocturnas en su compromiso con la causa felipista e, incluso, al cansancio generado por tener que compatibilizar sus responsabilidades en el Tribunal de la Rota y en la Penitenciaría con su dedicación a combatir dialécticamente y con argumentaciones teológicas a los apologistas de los derechos sucesorios de Carlos de Austria; de esta forma refería sus quehaceres divulgativos realizados en Roma en una misiva que le envió el 7 abril de 1709:

... salieron contra de mí los theólogos, frayles, canonistas y letrados contra de mis proposiciones, informé a Su Santidad durando muchas y se puso serenísimo contra su natural y genio, y yo crecía en valor y espíritu porque me había bien encomendado a Dios, y viéndome tan cansado el último, y que no tenían respuesta mis razones no dexando Santo Padre, ni doctor de la Iglesia que no citasse, ni concilios, ni cánones, ni bullas Pontificias, ni doctores de todas las naciones (...), y me respondió estaba satisfecho y que quantas razones yo decía eran fundadas y que no tenían error alguno, y le pedí licencia por informar al Sacro Collegio y me la concedió, pero que en quanto al informar al consistorio junto que me daría la respuesta, pero este acto que por mí era tan deseado fue impedido de los enemigos del Rey por temerme, y certifico a V.S. (...) que me expliqué bien con los cardenales, y como durava tantas oras quedaba cansadíssimo, y el mismo Papa me dijo que me quería vivo y no muerto, y que no lo tomasse con tanto vigor... ${ }^{17}$.

15 Carta del marqués de Prié al emperador fosé I. Roma, 2 de diciembre de 1708 (HaUs-, HoF -UND STAATSARCHIV [HHStA], Rom, Korrespondenz, 87, int. 6, ff. 163-184). Citada en David MARTÍN Marcos, Fosé de Molines, un ministro catalán al servicio de Felipe $V$ en Roma durante la Guerra de Sucesión Española, en Pedralbes, 28 (2008), p. 256. A este respecto el mencionado Marqués de Prié reconocía que las protestas presentadas por los representantes diplomáticos borbónicos afligían el ánimo del Sumo Pontífice. Francesco Valesio, Diario..., p. 256.

16 Documento citado.

17 AHN, Estado, leg. 4813. 
Desde luego, el ímpetu propagandista que destilaba José Molines en sus actuaciones le llevó a superar los límites de los comportamientos habitualmente esperables en un eclesiástico de su nivel representativo, puesto que en septiembre de 1711 llegó, incluso, a colocar carteles en el edificio de la Dataría instando a los españoles a abandonar Roma dentro del contexto de represalias adoptadas por Felipe $\mathrm{V}^{18}$; en concreto, esta actitud insumisa a la autoridad del Papa le reportaría la excomunión, la suspensión a divinis y también de su cargo de auditor ${ }^{19}$. Evidentemente, su conducta se había encontrado con la censura activada por la Santa Sede que pretendía erradicar aquellos mensajes publicitarios difundidos por los partidarios de Felipe de Anjou o de Carlos de Austria que hubieran cuestionado el posicionamiento de Su Santidad y del Colegio Cardenalicio en las diferentes fases de la crisis sucesoria española; de ahí la condena a textos propagandísticos felipistas como la Relación de lo sucedido en Roma, sobre el reconocimiento del Archiduque; concordados entre el Papa y Rey de Romanos, el cual fue reprobado mediante una bula promulgada por Clemente XI el 2 de octubre de $1709^{20}$. Esta decisión contrastaba con lo sucedido unos años antes, como consecuencia de la ceremonia de coronación en Viena del segundo hijo del Emperador Leopoldo I como rey de España, celebrada el 12 de septiembre de 1703, pues el Santo Padre se había decantado por ordenar la prohibición de exhibir retratos del Archiduque con distintivos regios, así como impresiones de manifiestos en los que se le otorgase el título de monarca; prueba de ello sería la frustrada iniciativa del conde de Lamberg -Embajador Imperial-, quien estuvo obligado a desistir de su intención de exponer públicamente una pintura de Carlos III en la Iglesia Nacional de Santa María del Ánima ante las amenazas expresadas por el Papado $^{21}$. En todo caso, en esta lucha por la divulgación de la imagen de los dos aspirantes a la Corona de España en la ciudad de Roma, Clemente XI adoptó una

18 Unos meses antes, en enero de 1711, daba muestras de la utilización de los medios impresos dentro de su campaña publicitaria; no en vano, Molines ordenó publicar en Roma una relación de sucesos sobre la victoria de Brihuega. Francesco VALESIO, Diario..., pp. 418-419.

19 Miguel Ángel OCHOA BRUN, Embajadas rivales. La presencia diplomática de España en Italia durante la Guerra de Sucesión, Ministerio de Asuntos Exteriores, Madrid, 2002, p.73.

20 Bula Quem siculo ad Apostolatus nostris notitiam pervenit, del papa Clemente XI, condenando la Relación de lo sucedido en Roma sobre el reconocimiento del archiduque (Carlos VI, emperador), entre el Papa y el Rey de Romanos (fosé I, emperador) (REAL ACADEMIA DE LA HISTORIA [RAH], col. «Salazar y Castro», ms. 9/278, fols. 52-54. oai:bibliotecadigital.rah.es:46491).

21 A la práctica de la exhibición de los retratos de Felipe de Anjou y Carlos de Austria en la ciudad de Roma durante la crisis sucesoria se ha dedicado un estudio específico. Diane H. BODART, Phillipe Vou Charles III? La guerra des portraits à Rome et dans les royaumes italiens de la couronne d'Espagne, en Antonio ÁlVAREZ-OSSORIO, Bernardo J. GARCÍA y Virginia LEÓN (eds.), La pérdida de Europa. La guerra de sucesión por la Monarquía de España, Fundación Carlos de Amberes, Madrid, 2007, pp. 99-133. 
actitud más equilibrada en 1706 al intervenir en la disputa sostenida entre el cardenal Grimani y el Duque de Uceda impidiendo que se luciesen retratos de ambos príncipes en el templo de San Carlos Borromeo ${ }^{22}$.

\section{FESTEJOS Y CEREMONIAS EN LA «CIUDAD ETERNA»: LA ESCENIFICACIÓN PÚBLICA DE LA DISPUTA SUCESORIA}

Por otro lado, la organización de festejos y celebraciones para exaltar las efemérides, victorias ${ }^{23} \mathrm{y}$ acontecimientos relacionados con las dos dinastías no difieren en esencia respecto al contenido general de los mensajes expresados en los territorios de la Monarquía Hispánica ${ }^{24}$, de forma que pretendía constituirse en una forma de lenguaje expresivo de la contienda sucesoria en la escena pública. Al mismo tiempo su ritual instaba a los diferentes sujetos diplomáticos, políticos y eclesiásticos residentes en Roma al compromiso con una de las dos causas de manera que sutilmente se les invitaba a este tipo de actos con el fin de que tomasen partido; no en vano, la simple presencia de éstos en los eventos era considerada un gesto de apoyo a uno u otro príncipe ${ }^{25}$. Ciertamente, en este marco resultaba complicado mantener la neutralidad ante esta táctica de con-

22 David Martín Marcos, fosé de Molines..., pp. 254-255.

23 A modo de ejemplo, la celebración en Roma de la victoria de Brihuega por los partidarios de Felipe de Anjou se llevó a cabo con medios semejantes a como se efectuaba habitualmente en los dominios de la Corona Española; actos solemnes, canto del Te Deum, impresión de relaciones de sucesos, entre otras fórmulas. De este ceremonial se dejaba constancia en el Diario di Roma, entre otras fechas, el 9 de enero de 1711 cuando se decía: «Questa mattina nella Chiesa di S. Giacomo de Spagnoli doppo la messa grande da quei capellani fu cantato il Te Deum laudamus col suono del l'organo per la vittoria giá publicata» (Francesco VALESIO, Diario..., p. 422).

24 Se ha preferido no insistir específicamente en este aspecto en el ámbito de los dominios de la Monarquía Hispánica en España y América atendiendo a que ha sido un espacio tratado ya en varias publicaciones; puede verse: David GONZÁLEZ CRUZ, Guerra de religión..., pp. 195-231. David GonZÁLEZ CRUZ, Propaganda..., pp. 19-26.

25 En este marco se comprueba, a modo de muestra, que la celebración de la fiesta de San Carlos -onomástica del Archiduque- generó una división en los miembros del Colegio Cardenalicio de forma que los cardenales Giudice, Tramoglie y Acquaviva decidieron no asistir con el fin de no contribuir a posibles repercusiones publicitarias favorables a los intereses de la Casa de Austria, a lo que podría haber ayudado, además, la presencia del Marqués de Prié. Así se desprende del relato de los hechos correspondientes al cuatro de noviembre de 1708: «Festa di S. Carlo, onde per togliere l'impegno di esporre il ritratto nella Chiesa della nazione milanese al Corso dedicata a detto santo, S. Beatitudine vi tenne cappella pontificia, essendovisi portato in carroza con gli cardinali Paracciani e Vallemani e vi assisté quasi tutto il S. Collegio, alla reserva de cardinali Giudice, Tramoglie et Acquaviva. Andò a vedervi la cappella el marchese di Prié con monsignor di Cauniz sopra un coretto a lato dell'altare maggiore, al quale il pontefice nell'entrare diede la benedizzione, alzandovi lo sguardo» (Francesco VALESIO, Diario..., pp. 182-183). 
vidar a personas concretas poniéndolas en la tesitura de que su participación o ausencia fuesen interpretadas como adhesión, desafección o desprecio; así difícilmente había alternativa para preservar la imparcialidad, a pesar de que algunos intentaron resistirse, como fue el caso del Príncipe Livio Odescalchi, quien con el fin de cumplir con la invitación del Duque de Uceda sin ser visto por los austracistas solicitó observar desde su coche la serenata programada en la Plaza de España para el día 30 de abril de 1701, en vísperas de la onomástica de Felipe de Anjou $^{26}$. Por supuesto, recibió de este Embajador una velada amenaza si no abandonaba la intención de disimular su presencia. Por su parte, otros invitados como el condestable Colonna, Borghese y Palestrina se excusaron; no obstante, en represalia Uceda no los recibió cuando pretendieron hacerle visitas. De este modo, las recepciones y fiestas preparadas en Roma por el Embajador Imperial, por los cardenales Grimani o Giudice ${ }^{27}$, por el príncipe de Avellino -Embajador de Carlos de Austria- o por la Embajada de Felipe V trataban de orquestar un teatro de escenificación de las lealtades, aunque fuesen forzadas, cuyo objetivo esencial no era otro que implicarlos y publicitarlos como referentes que animasen a otros a unirse a sus respectivas causas.

En este ambiente de recurrentes actividades festivas, la ciudad de Roma se convirtió en un espejo de los vaivenes que atravesaban los apoyos internacionales

26 Miguel Ángel OCHOA BRUN, Embajadas..., pp. 136-137.

27 En este lenguaje de las «lealtades» el mencionado cardenal Giudice y su compañero Tramoglie, declarados defensores de la causa borbónica, decidieron no participar en las ceremonias públicas junto al Santo Padre, manifestando así el desacuerdo de éstos con la decisión de reconocer al Archiduque como rey con el título de Carlos III; de ello quedaba registro testimonial el uno de abril de 1709: «Per mostrare il disgusto ricevuto dalla corte di Parigi e Madrid della conclusione della pace, con la ricognizione in re di Carlo III, tra questa corte e quella di Vienna, non sono comparsi alle capelle et altre funzioni publiche tenute da S. Beatitudine nella corrente settimana gli cardinali della Tramoglie e del Giudice». En este mismo sentido, la entrada solemne en Roma del Príncipe de Avellino -Embajador de Carlos III-, efectuada el 18 de enero de 1711, solamente contó con la participación de los cardenales partidarios de la Casa de Austria y los neutrales, si bien se contabilizaron la nada despreciable cantidad de 84 miembros del Sacro Collegio. Francesco VALESIO, Diario..., pp. 255 y 423-425. Por otra parte, en torno a las connotaciones políticas que se observaban en el funcionamiento de las diferentes facciones existentes en el Colegio Cardenalicio son esclarecedores los siguientes estudios: Gianvittorio SIGNOROTTO, The Squadrone Volante: Independent cardinals and european politics in the second half of the seventeenth century, en Gianvittorio SignOROTTO y María Antonietta VisCEgLIA, Court and politics in Papal Rome, 14921700, Cambridge University Press, 2002, pp. 177-211. Antonio MENNITI IPPOLITO, Il Segretario di Stato e il Segretario dei memoriali: la difficile ricerca di stabilità all'interno della Curia papale prima e dopo l'abolizione del nepotismo (sec.XVII-XVIII), en Archivum Historiae Pontificae, 46 (2008), pp. 75 106. Steffano TABACCHI, Cardinali zelanti e fazioni cardenalizie tra fine Seicento ed inizio Settecento, en Gianvittorio SignOROTTO y Maria Antonietta VisCEgLIA (eds.), La Corte di Roma tra cinque e seicento, «teatro» della politica europea, Bulzoni, Roma, 1998, pp. 139-165. 
a las dos dinastías en litigio, de manera que las obras musicales, las representaciones teatrales, las luminarias, los fuegos de artificio, las serenatas, los Tedeum y la exhibición de escudos de los Austrias o Borbones en las puertas de los palacios romanos, entre otras formas de expresión insertadas en el lenguaje propagandístico, permitían pulsar a los diplomáticos y agentes de las potencias implicadas en el conflicto bélico sobre la acogida que iban obteniendo la entronización de Felipe V, la proclamación de Carlos III en Viena, el nacimiento del príncipe Luis, las bodas reales, o el reconocimiento de Carlos de Austria por la Santa Sede, por citar algunos hechos significativos ${ }^{28}$.

De igual manera, los contendientes examinaban con lupa cualquier ceremonia promovida por el Sumo Pontífice por si hubiera en ellas algún gesto proclive a uno de los aspirantes al Trono de España ${ }^{29}$; a modo de ejemplo, el estreno del oratorio de los santos Justo y Pastor en la Iglesia de San Girolamo della Carità en 1708 fue interpretado como un guiño de Clemente XI a los Borbones por tratarse de mártires galos ${ }^{30}$. Por el contrario, la celebración de la onomástica de Carlos de Austria mediante una misa en la Iglesia de San Carlos en noviembre de 1710 suponía un refrendo a su reconocimiento regio; de ahí que la Gaceta de Barcelona -órgano informativo y publicitario de la Corte del Archiduque- divulgara con detalle este posicionamiento de la Santa Sede para conocimiento de todos sus lectores ${ }^{31}$ :

ROMA. 8 de noviembre. Su Santidad tuvo Capilla en la Iglesia de San Carlos el día de este Santo, donde concurrieron muchos Cardenales y ofició la Missa el Cardenal Dada. Aquella misma noche celebró el Nombre, y Años del Rey Católico, su Embaxador Príncipe de Avellino (...), aviendo concurrido a ella (...) el Cardenal Barberino, y todos los prelados vassallos de la Augustíssima Casa (...).

28 En relación con las celebraciones festivas organizadas en Roma en la centuria precedente o sobre sus implicaciones políticas internacionales puede verse: María Antonietta VISCEGLIA, Guerra, diplomacia y etiqueta en la Corte de los Papas (siglos XVI y XVII), Ediciones Polifemo, Madrid, 2010, pp. 95-132. Martine BOITEUX, Fêtes y traditions espagnoles à Rome au XVIIe siècle, en Marcello FAGIOLO y María Luisa MADONNA (eds.), Barocco romano e barroco italiano. Il teatro, l' effimero, l'allegoria, Gangemi, Palermo, 1985, pp. 117-134.

29 En este contexto se integraría la revocación de la organización de una procesión con la Santísima Virgen en Santa María la Mayor y San Juan de Letrán a causa de la actitud manifestada por el Marqués de Priè ante la posibilidad de que este hecho pudiera favorecer la excitación de la población contra el Emperador en diciembre de 1708. Gianvincenzo GRAVINA, Curia romana..., p. 309.

30 Miguel Ángel OCHOA BRUN, Embajadas..., p. 143.

31 Gazeta de Barcelona, $\mathrm{n}^{\circ}$ 29, 30 de noviembre de 1710 (ARChivio SEgreto VatiCANo [ASV], Segr. Stato, Spagna, vol. 203, fol. 581r). 
Realmente, estos cambios de discurso en el ceremonial vinculado al titular de los Estados Pontificios dejaba interrogantes a su confesada intención de instalarse en la neutralidad y de ofrecerse como mediador para conseguir la paz entre las dos dinastías ${ }^{32}$, puesto que desde un principio al mismo tiempo que manifestaba una cierta complicidad con Felipe $V$ en el lenguaje empleado con motivo de su llegada al Trono, también se resistía a reconocerle todos los atributos propios del Rey de España, especialmente su investidura como monarca de Nápoles.

\section{GESTIÓN Y REPERCUSIONES DEL VALOR DISCURSIVO DERIVADO DE LAS MODIFICACIONES DE LA POSICIÓN DE LA SANTA SEDE}

La ambigüedad medida conscientemente y demostrada por Clemente XI respecto a los candidatos que optaban a la Corona de España generaba, como es lógico, repercusiones publicitarias y una apariencia diplomática que conducía a equívocos interpretativos entre los representantes de ambos bandos; sin duda, el testimonio de Nicolás Erizzo -Embajador de Venecia en la Santa Sede- así lo atestiguaba cuando describía la disparidad de opiniones y confusión reinante entre los embajadores de Francia y Austria acreditados en Roma:

Atraídos de estas finísimas lisonjas, los Ministros Cesáreo y de las Dos Coronas han creído siempre en secreto al Papa muy de su parte e inclinado a los intereses de sus Príncipes ${ }^{33}$.

Sea cual fuere la convicción que en determinado momento hubieran tenido los ministros imperiales como consecuencia de la habilidad aduladora que en el corto plazo demostró Albani, lo cierto es que sus manifestaciones durante los primeros años de su pontificado sirvieron a los partidarios de Felipe de Anjou para sustentar las bases de una propaganda de contenido religioso fundamentada en el argumento del beneplácito otorgado por Clemente XI al nieto de Luis XIV.

32 Entre los testimonios referentes a la actividad conciliadora de Clemente XI se halla el que se reproduce a continuación: «... ofreciéndose mediador para atajar la guerra que se temía, escribiendo al rey Luis y al emperador. Mandó pasar a Viena al nuncio Davia...» (Francisco Castellví, Narraciones históricas, vol. I, Fundación Francisco Elías Tejada y Erasmo Pércopo, Madrid, 1997, p. 193).

33 Relación del Caballero Nicolás Erizzo, Embajador de Venecia en Roma, de Inocencio XII y Clemente XI (BIBLIOTECA NACIONAL [BNE], ms. 283, fol. 258). También publicado en Bartolomeo CECCHETTI, La Repubblica di Venezia e la Corte di Roma, nei rapporti della religione, Venecia, 1874, vol. II, pp. 323-348. 
En este sentido, no puede olvidarse que en el marco de una crisis sucesoria en la que se cuestionaba la legitimidad de los pretendientes a la Corona se extendía la tesis entre los hispanos y entre los teólogos, juristas y publicistas felipistas de que el Santo Padre era la persona a la que correspondía dirimir la disputa dinástica y el único que tenía potestad por «derecho divino y positivo» ${ }^{34}$ para anular el juramento de fidelidad a Felipe $\mathrm{V}^{35}$; así lo divulgaban diferentes impresos editados que expandieron una opinión que, paradójicamente, se volvió contra sus mismos autores cuando el Pontífice Romano reconoció unos años más tarde, en 1709, a Carlos de Austria como Rey Católico, una vez que el Emperador y los austracistas se habían esforzado en conseguirlo tras valorar el efecto publicitario y político que generaría esta decisión. En concreto, respecto a la autoridad del Papado en el litigio sucesorio se refería en estos términos un folleto editado en la imprenta madrileña de Antonio Vizarrón ${ }^{36}$ :

Es una causa tan soberana la del derecho, y sucessión en los Reynos, que después de Dios, solo toca su juizio a los Reyes, a los Reynos en sus Cabezas, a la Cabeza de la Iglesia, que mira a los Reyes, y Reynos como hijos; a estos solos está prometida de Dios la luz para el acierto.

Aunque Clemente XI procuró ofrecer un perfil de equidistancia calculada de sus relaciones con Carlos de Austria y Felipe de Anjou desde principios de su pontificado; sin embargo, diversos ceremoniales, comunicaciones epistolares y actos protocolarios ofrecieron a los felipistas las herramientas dialécticas necesarias para justificar este conflicto dinástico e internacional entre dos príncipes católicos como una «guerra de religión», en la que el candidato borbónico contaba con recursos suficientes para ofrecer una apariencia creíble de complicidad de la Santa Sede. La primera de las mencionadas herramientas fue proporcionada por Su Santidad el 6 de febrero de 1701 al remitirle una carta a Felipe de Anjou, en el contexto de su entronización como monarca, en cuyo texto le denominaba «Rey Católico»y «Rey de las Españas» y, además, le sugería que gobernase de la siguiente manera para demostrar que su regia condición la había conseguido con

34 Juan Melo y GIRón, Celo católico y español por la religión y por la patria..., Valencia, Imp. Antonio Bordázar, 1708, editado en María Teresa PÉREZ PICAZO, La publicística española en la Guerra de Sucesión, 2 vols., CSIC, Madrid, 1966, vol. II, pp. 112-114.

35 Memorial que a la inclyta generosa nación española ofrece D. Alonso Fernando Gutiérrez, caballero de el antiguo Orden de Santiago, Imprenta de Alonso Fernández Fontecha, Lima, 1706, p. 33.

36 Doctrina christiana. Explicada en ocho christianas máximas, muy útiles, y necesarias a los vassallos para su Rey. Imp. Antonio Vizarrón, Madrid, s.d., p. 5. 
justicia: «Llenad tan dignamente el título de Católico, que nadie pueda escusarse de confessar, que le aveis tomado con justíssima razón» ${ }^{37}$; y, por si fuera poco lo dicho anteriormente, para terminar le otorgaba una «bendición apostólica» que era propicia a las interpretaciones interesadas de los defensores de su candidatura. Después de haber llegado a Felipe V una carta impregnada de estos reconocimientos, entraba dentro de la lógica que los encargados de la actividad publicitaria de sus derechos borbónicos valoraran como un regalo enviado por el Vicario de Cristo -el representante de la Divinidad en la Tierra- este mensaje redactado dentro del marco de la cortesía diplomática -posiblemente sin ser consciente del uso público que le iba a dar su destinatario-; por ello no desaprovecharon este obsequio de incalculable valor para sus pretensiones apresurándose a transformarlo en un arma arrojadiza contra las aspiraciones del Archiduque mediante el procedimiento de publicarlo con la correspondiente licencia real en dos idiomas -francés y español- con el objetivo de que funcionase de aval notorio de su toma de posesión y complemento de los argumentos manejados para que las Cortes de Castilla lo jurasen y proclamasen tres meses más tarde, el 8 de mayo de 1701.

En esta línea trazada que pretendía implicar en mayor medida a la Santa Sede se reforzó la exhibición pública de los representantes de la jerarquía de la Iglesia Católica junto al Duque de Anjou en las funciones y actos solemnes presididos por él, especialmente en eventos tan simbólicos como la entrada pública que hizo en Madrid el 14 de abril de 1701, para lo cual se dieron las órdenes oportunas a los caballerizos y al Mayordomo Mayor con objeto de que colocasen al Nuncio de Su Santidad inmediatamente detrás de «Su Real Persona», seguido de los cardenales y precediendo a toda la comitiva de acompañantes ${ }^{38}$.

Estas formalidades respetuosas con el «statu quo» derivado del testamento de Carlos II situaban al Pontífice Romano como protagonista de la publicística felipista que glosaba sus actos protocolarios y diplomáticos como si fuesen refrendo de la legitimidad del nieto de Luis XIV; así se presentaba públicamente, entre otros gestos, la aceptación del Duque de Uceda como Embajador de España, la conservación del Nuncio apostólico en Madrid, el envío del Cardenal Barberini a Nápoles en calidad de legado extraordinario ante Felipe de Anjou ${ }^{39}$, la admisión y concesión de bulas a los obispos presentados para las diócesis hispa-

37 Copia del Breve, que nuestro muy Santo Padre Clemente XI escribió al Rey nuestro señor Don Felipe Quinto (que Dios guarde) en respuesta de su Real Carta de enhorabuena sobre su ascenso a la Tiara (BUS, Fondo Antiguo, Estante 111, $\mathrm{n}^{\circ}$ 12, impreso 20).

38 Documento dirigido al Marqués de Mancera el 10 de abril de 1701 (ASv, Arch. Nunz. Madrid, vol, 56).

39 ARChivo de la EMbajada de EsPaÑa CERCA DE la SANTA SEDE (AEESS), vol. 51, fols. 95-108. 
nas $^{40}$, la presencia del Cardenal Archinto -legado a latere - en la boda con María Luisa de Saboya como responsable de la entrega de una rosa de oro obsequiada por Su Santidad ${ }^{41}$, o la embajada extraordinaria que hizo el Príncipe de Santo Buono a Su Santidad por encargo de la reina en $1702^{42}$.

A este posicionamiento del Santo Padre en los primeros años de la crisis sucesoria -por supuesto equívocamente distante de la imparcialidad aparente confesada- se sumó a mediados de 1703, antes de la coronación de Carlos de Austria en Viena, la prohibición de editar y difundir en Roma cualquier panfleto que se refiriese a la condición regia del Archiduque ${ }^{43}$. Sin duda, esta actitud persecutoria de los partidarios imperiales podía ser entendida como una toma de partido por el candidato borbónico; por tanto, la Santa Sede tendría dificultades para que fuesen verosímiles sus explicaciones en el sentido de que las legaciones enviadas a Felipe $\mathrm{V}$ y las actuaciones diplomáticas eran estrictamente actos de cortesía ${ }^{44}$.

Con estos precedentes, fuera cual fuese el discurso de fingida neutralidad de Clemente XI, lo cierto es que Felipe V con estas escenificaciones protocolarias se había dotado de excelentes recursos propagandísticos emanados de la sede del Vicario de Cristo que le permitían publicar mediante impresos, tanto en sus reinos de Europa como de América, haber sido reconocido como monarca católico de «las Españas» por el denominado «Padre Común» que descansaba en la «Silla de San Pedro» ${ }^{45}$. Precisamente, la publicística felipista y la literatura religiosa editada por sus partidarios afirmaban que este argumento contribuía a que los españoles lo jurasen como Rey, lo defendieran y lo veneraran como tal ${ }^{46}$. De este

40 Diálogo entre dos opuestos afectos de maestro, y discípulo, sobre lo que passa en la Monarquía de España. Sevilla, 1706, p. 21.

41 Documento de Clemente XI con motivo de los desposorios de Felipe de Anjou y María Luisa de Saboya. Roma, 8 de agosto de 1701 (ASV, Arch. Nunz. Madrid, vol. 50). ANTONIO UbILla Y MEDINA, Successión de el Rey D. Phelipe V Nuestro Señor en la Corona de España; diario de sus viajes, Imp. Juan García Infanzón, Madrid, 1704, p. 319.

42 AEESS, vol. 51, fols. 63-66.

43 David Martín Marcos, El Papado y la Guerra de Sucesión española, Madrid, Marcial Pons, 2011, p. 98.

44 Paulino Castañeda Delgado, Clemente XI y la Guerra de Sucesión, en La Guerra de Sucesión en España y América. Actas de las X Jornadas Nacionales de Historia Militar, Cátedra «General Castaños», Madrid, 2001, p. 869.

45 Documento de Felipe V redactado en Plasencia el 30 de abril de 1704 (Archivo General de Indias [AGI], Charcas, 263, fol. 121).

46 FraY José DE HARO, Rogativa y fiesta a Nuestra Señora de la Iniesta, patrona de la Ciudad de Sevilla, celebrada (...) en 13 de mayo deste año de 1704 (...) por nuestro muy Catbólico Monarca, y Señor Don Phelipe V (que Dios guarde) en paz con los católicos príncipes, y victoria de los enemigos hereges. Y sermón... Imp. Juan de la Puerta, Sevilla, 1704, pp. 9-10. 
influjo de la decisión del Papado en la mentalidad hispana daba cuenta, entre otros eclesiásticos, el doctor Antonio Muñoz:

(...) entró nuestro Monarca Phelipe Quinto en la possessión de aquestos Reynos suyos: no porque darle entrada fuesse clemencia, siendo justicia; sino porque nuestro Santíssimo Padre Clemente Undécimo lo recibió por tal (...), de donde infiero, que aunque no huviesse tantos, y tan justificados motivos como ay, para averle constituido en la Dignidad Real, era este solo suficiente en la grande fee de los Españoles, para averle recibido, y para averle jurado, y después para reconocerle, para venerarle, para conservarle, y para defenderle ${ }^{47}$.

Con todo, entre el conjunto de fórmulas ceremoniales y diplomáticas procedentes de la Santa Sede que favorecían a la imagen de Felipe V como Rey entre los súbditos hispanos se daba como contraste negativo a sus intereses publicitarios la decisión de Clemente XI, de indudable carga simbólica, consistente en no concederle la investidura del reino de Nápoles; de esta forma, Su Santidad pretendía demostrar que no se decantaba por ninguno de los dos candidatos al Trono a pesar de las constantes peticiones del Embajador Imperial y de los representantes borbónicos ${ }^{48}$. No obstante, el Duque de Uceda, conociendo el efecto propagandístico multiplicador que tenía la mencionada investidura, y tras haberla solicitado «diversas veces en el término de seis meses», puso en marcha la táctica de forzar la aceptación del Pontífice ordenando a Alonso Torralba -Agente de la Embajada Española- que entregase en el Tribunal de la Cámara Apostólica un caballo blanco y los 7.000 ducados estipulados en el ritual exigiendo que se levantase acta de ello ${ }^{49}$; sin embargo, pese al objetivo buscado con este acto realizado el 28 de junio de 1701, víspera del día de San Pedro, se vieron obligados a desistir al recibir el rechazo de la Curia Cardenalicia y la indignación del Santo Padre por esta artimaña. Realmente, este era el principal punto de debilidad de la campaña de «guerra de religión» organizada por la Administración Borbónica y sus partidarios; de ahí el interés demostrado en subsanar con inmediatez la formalización de la ceremonia de la Accanea. Ciertamente, el hecho de que el máxi-

47 Antonio MuÑoz Gordillo HorTiz, Feliz anuncio de los gloriosos triunfos, y felizes sucessos, que ban de conseguir de todos sus enemigos las siempre invencibles armas de Nuestro Rey, y Señor Don Phelipe Quinto (...), Imprenta de Manuel Ruíz de Murga, Madrid, 1706, p. 13.

48 Pedro VolTes Bou, La Guerra de Sucesión, Planeta, Barcelona, 1990, p. 135. Henry Kamen, Felipe V. El rey que reinó dos veces, Ediciones Temas de Hoy, Madrid, 2000, p.33.

49 De ello quedaba constancia en un documento relativo a la protesta realizada por la Embajada de España sobre la presentación de la Accanea fechado el 28 de junio de 1701 (AEESS, vol. 219, fols. 39v y 40r). 
mo responsable de la Iglesia de Roma no hubiese permitido la ejecución de este acto simbólico fue la causa de la intensificación del debate sobre la legitimidad del acceso de Felipe de Anjou a la Corona de España; sobre este cuestionamiento de la condición regia se hacían eco, incluso, diversos manuscritos e impresos felipistas editados durante la Crisis Sucesoria que trataban de justificar esta carencia relacionada con el reino de Nápoles ${ }^{50}$. Así lo expresaba uno de ellos publicado en $1702^{51}$ :

Para Nápoles se alega la sutileza, de que no está dada la investidura por el Papa, y assí que no puede el Señor Felipe V, llamarse Rey de sus Provincias. Pero se responde con facilidad, sin entrar en la questión de este derecho, a que muchos responden, que la investidura no haze Rey, sino que lo supone, sirviendo esta ceremonia para la autoridad, y no para el derecho (...).

En este contexto, los imperiales desplegaron su maquinaria de comunicación en Roma distribuyendo por la ciudad numerosos carteles que afirmaban que el juramento de vasallaje efectuado por la nobleza napolitana al Duque de Anjou no contaba con valor jurídico por no disponer de la correspondiente investidura del feudo ${ }^{52}$. En cualquier caso, esta primera contrariedad de origen eclesiástico encontrada por los felipistas para la elaboración de los discursos justificativos de los derechos a la Corona se ampliaba en cuanto a repercusión en la opinión pública hispana con el reconocimiento de Carlos de Austria como Rey de España efectuado por Clemente XI en 1709; no en vano, como advertía el auditor José Molines, era un incentivo para que se reafirmase y se extendiera la rebeldía y la desafección al Borbón en los reinos de la Monarquía ${ }^{53}$, al mismo tiempo que posibilitaba una mayor identificación de los clérigos con la causa austracista ${ }^{54} \mathrm{y}$, por tanto, que se incrementase la labor de divulgación de estos profesionales de la comunicación social en los púlpitos, en los confesionarios y en las imprentas en favor de Carlos de Austria. Ni siquiera el hecho de que el reconocimiento papal se hubiera formulado en un marco de presión de las fuerzas armadas imperiales tras la conquista

50 Juan Alfonso GUERRA, Discursos conjeturales y precisas consecuencias que funda la lealtad y razón sobre la poca que adquiere el Señor Archiduque de la prosecución de la guerra (...) (BNE, ms. 5999, fols. 152191). Cfr. María Teresa PÉREZ PICAZO, La publicística ..., vol. II, p. 263.

51 Clara demonstración, de las operaciones de las dos Coronas, y vrebe respuesta a los cargos de los Imperiales, Imp. Pedro Nassau, Colonia, 1702, p. 6.

52 David MarTín Marcos, El Papado..., p. 94.

53 Carta de Monseñor Molines al Marqués de la Mejorada (ARChIVO General DEL Ministerio DE Asuntos EXTERIORES DE EsPaÑa [AMAEx], Fondo Santa Sede, leg. 275).

54 Rosa María Alabrús Iglesias, Felip V i l'opinió dels catalans, Pagès editors, Lleida, 2001, p. 218. 
de la ciudad de Comacchio $^{55}$ fue un obstáculo insalvable para que la obligada obediencia de los creyentes al Pontífice romano generara nuevos adeptos al Archiduque; no obstante, sí era motivo para que la Administración borbónica y sus publicistas iniciasen una campaña de desprestigio de las circunstancias en que el Santo Padre debió pactar su decisión con los representantes de la Casa de Austria con la finalidad de limitar al máximo el impacto que esta noticia tuvo en la mentalidad católica de los hispanos. Esta operación de descrédito ante la opinión pública estuvo encabezada desde un principio por el propio Felipe V, quien inmediatamente después de conocer la resolución dirigió una carta a todos los prelados, iglesias, universidades y órdenes religiosas de los reinos hispánicos -también difundida en formato impreso- insistiendo en que el reconocimiento del Archiduque no tenía validez por haberse dictado como consecuencia de la violencia ejercida en los estados pontificios y por el temor causado en el Papa; incluso trataba de reafirmar su discurso aludiendo a un testimonio privado realizado -según él-por Clemente XI a los representantes de Luis XIV, en el que se disculpaba de su actuación por haber sido fruto de la intimidación militar a la que había estado sometido ${ }^{56}$ :

Empezaron las conferencias a vista de la armada persuasión de los Exércitos (...), fueron a ver a Su Santidad los Ministros del Rey Christianíssimo mi Abuelo, y los que yo tenía residentes en aquella Corte, y les enseñó los (artículos) acordados, disculpándose con la violencia que padecía, y confessando tendrían razón en todo lo que executassen; añadiendo (...); y conociendo la indispensable obligación en que ponía a las dos Coronas, para manifestar a todo el mundo con públicas demostraciones la nulidad, y injusticia, de quanto se avía hecho, y se hiziesse mientras las fuerzas de los Alemanes prevaleciessen en Italia, y faltasse la libertad, independencia, con la qual deben obrar los Papas, repitiendo la necessidad, estrechez, y que convenía apelar de un Papa cautivo, a un Papa puesto en libertad.

Con este argumento, no solo declaraba la nulidad del reconocimiento, sino que incluso se eximía de la responsabilidad moral y religiosa en la campaña propagandística que emprendía contra la decisión del Pontífice manifestando que

55 La pérdida de Comacchio, núcleo urbano estratégico en la desembocadura del río Po y de gran interés económico para la Santa Sede, fue el golpe definitivo a la defensa militar que llevó a cabo la Santa Sede. José María MARQUÉs, Las instrucciones de la nunciatura de Barcelona (1710-1713), en Anthologica Annua, 24-25 (1977-1978), pp. 684-686.

56 Copia de Carta, que el Rey ha resuelto se escriva a los Prelados, Iglesias, Universidades y Religiones... Aviendo los alemanes invadido los estados de la Iglesia (...), y convencido su temor la independencia de la Silla Apostólica... (REAL BiblioTeCA [RB], III/6468 [4], fols. 1-2). 
el mismo Clemente XI supuestamente había confesado que «tendrían razón en todo lo que ejecutasen» a partir de entonces a causa de su resolución respecto al candidato austriaco; así pretendía liberarse de la autoridad papal, pero con la habilidad de aparentar ante sus súbditos que el mismo Santo Padre comprendía este modo de actuar. Similares razonamientos utilizaba el mariscal de Tessé, Embajador francés en Roma, en una carta escrita a Su Santidad el 14 de diciembre de 1708, cuando ya se preveía el giro de los acontecimientos, pues le advertía que en el caso de dar el paso de avalar las aspiraciones de Carlos de Austria abría el «peligroso camino» de validar el principio de que los más fuertes impusiesen las leyes estableciendo el temor por encima de «la religión, el honor y la justicia $\gg^{57}$. En esta misma línea, el relato de sucesos confeccionado por los promotores de la propaganda borbónica con el título de Relación de lo sucedido en Roma sobre el reconocimiento del Archiduque..., reiteraba que este acontecimiento se había producido a causa de que las tropas del General Daun y del Príncipe de Darmestar estaban amenazando «las puertas de Roma ${ }^{58}$ y como resultado de que los ministros del Vicario de Cristo deseaban conservar sus casas y haciendas «juzgando podían peligrar».

Sobre esta base discursiva, asentada previamente por Felipe de Anjou y los diplomáticos borbónicos residentes en la capital de los Estados Pontificios, se desplegó una intensa actividad publicitaria en prosa y en verso que aludía al decreto del Papado efectuado -según los textos impresos- bajo opresión ${ }^{59}$ y por miedo a la invasión prevista del ejército de la Casa de Austria y a la falta de respeto a la inmunidad de la Iglesia ${ }^{60}$.

Sea cuales fueren las circunstancias en las que se produjo la resolución de la Santa Sede, resulta lógico que se resistiera a soportar una campaña de desprestigio de la autoridad papal tal como la que iniciaron los Borbones, incluso antes de que se firmase el acuerdo entre el Cardenal Paulucci y el Marqués de Prié el 15 de enero de 1709; en respuesta a este ataque los austracistas difundie-

57 Renate de Froulay Tessé, Carta del Mariscal de Tessé a Clemente XI, y respuesta de éste (RB, II/2826, fols. 218-219).

58 Relación de lo sucedido en Roma sobre el reconocimiento del Archiduque, concordados entre el Papa y Rey de Romanos. Protesta echa por el Duque de Uzeda a Su Santidad y oficio que mandó el Rey se pasase con el Nuncio avisándole de su salida de España.

59 Segundo memorial del Pobre de las Covachuelas, al Doctor Bullón, este año de 1710, Imp. Juan de la Puerta, Sevilla, 1710, p. 6.

60 Así se expresaba, entre otras fuentes, en el siguiente folleto versificado: Desafío entre un felipense, y un calvinista, Imp. Francisco Garay, Sevilla, 1711. 
ron un impreso que atribuían a Clemente XI, en el cual trataban de defender la mencionada autoridad como Padre común y de reforzar su decisión afirmando que otros estados católicos y libres habían reconocido igualmente a Carlos de Austria y, al mismo tiempo, en la denominada «respuesta» enviada al Mariscal de Tessé -publicitada convenientemente- se aludía a la hipocresía de la dinastía francesa, a la que se acusaba de solicitar los consejos de la Silla Apostólica cuando eran favorables a sus intereses y, por el contrario, cuando preveía una determinación opuesta a sus deseos prefería acudir a los argumentos teológicos de la Sorbona ${ }^{61}$. Es más, en un texto impreso atribuido igualmente a Su Santidad -a pesar de que el Abad Lucini, ministro apostólico en Barcelona, negaba que procediera de la Santa $S_{e d e}{ }^{62}$, se pretendía proteger a su figura ante cualquier tipo de ofensa propagandística llegando a culpar a la Corona gala, en diciembre de 1708, de aliarse con estados musulmanes como Turquía y protestantes como Suecia en perjuicio de territorios católicos de Polonia, Silesia y Hungría ${ }^{63}$. A pesar de lo dicho, Albani en su intento de aparentar neutralidad, se excusaba ante los Borbones a través del mariscal de Tessé manifestándoles de este modo que el reconocimiento del Archiduque como Rey no significaba que Felipe de Anjou perdiera la condición regía:

Dejará de ser Rey Phelipe $5^{\circ}$ porque yo trate como Rey al Archiduque? No es nuestra intención dar ni quitar Reynos, sino quando nos buscan como Padre común sujetándose a nuestra: Pues si por tribunal havéis elegido las armas an de determinar ${ }^{64}$.

Con todo, en la batalla por la comunicación ante la opinión pública católica que mantuvieron los felipistas con la Santa Sede se valoraron informes y correspondencia de colaboradores de la Corona que no justificaban la actuación del Papado, ni siquiera ante la fuerza de las armas; entre ellos, José Molines dirigía una carta a Félix de la Cruz Haedo -Secretario del Consejo de Indias- expresándole su opinión de que la ausencia de libertad de Clemente XI era simplemente

61 Copia de la respuesta que en el año de 1708 dio Clemente XI al Mariscal de Tessé sobre asuntos de Estado. Roma, 15 de diciembre de 1708 (Ministère DES AFFAIRES ETRANGÈRES [AMAEF], Mémoires et documents, Espagne, 249, fols. 100-101).

62 Carta del Abad Lucini al Cardenal Paulucci-Secretario de Estado de la Santa Sede-, redactada el 25 de abril de 1711. Adjunta el siguiente impreso: Copia de carta, que se esparció en Roma, escrita por Su Santidad al Mariscal de Tessé, en respuesta de la que el dicho Mariscal escrivió a Su Santidad (ASV, Segr. Stato, Spagna, vol. 204A, fols. 279r, 290 y 301r-302v).

63 Copia de la respuesta que en el año de 1708..., Documento citado, fol. 102.

64 Doc. cit., fol. 100. 
una excusa, puesto que -según él- habría podido «hacer bien su oficio si hubiese querido, y si fue impedido, es porque lo quiso así por sus fines particulares ${ }^{65}$; esta beligerancia discursiva del Auditor de la Rota le llevaba a denominar, incluso, al Pontífice como enemigo de Felipe $\mathrm{V}$ por haber ordenado la publicación de un breve contrario al Borbón que fue distribuido y fijado por las esquinas de Roma. Por su parte, Francisco Portell -uno de los principales referentes del partido realista catalán, integrante de la Junta formada para la salida del Nuncio de España y miembro del Consejo de Castilla ${ }^{66}$-, en un informe elaborado el 12 de abril de 1709, calificaba la conducta del Santo Padre como injuriosa y planteaba que ante la violencia ejercida contra él por el Emperador tuvo la opción de haberse resistido a reconocer a Carlos de Austria como rey con las «Armas de la Iglesia» mediante el abandono de Roma de igual forma que lo habían hecho otros pontífices en casos semejantes ${ }^{67}$.

De todas formas, la estrategia publicitaria basculaba entre culpar a Albani de su comportamiento o excusarlo con el argumento de que su resolución había sido fruto de la presión militar; no obstante, el recurso discursivo del denominado «Papa cautivo» no fue exclusivo de la campaña de descrédito a su decisión planteada a partir de 1709 , pues disponemos de antecedentes -al menos desde 1705- que indican que la Embajada de España en Roma estaba forjando una imagen del Pontífice acomodada a las fuerzas armadas imperiales y a la privación de libertad como instrumento para desprestigiar su conducta; de ello es prueba la misiva enviada el 12 septiembre por el Duque de Uceda al Príncipe de Vaudémont-Gobernador de Milán- ${ }^{68}$ :

(El Papa) quiere más ser esclabo de ellos (tropas de los alemanes), que redimido de nuestras fuerzas que nunca admitirá aunque se exponga a mayores perjuizios...

El retrato de un «Papa esclavo» que obraba sin autonomía convenía, desde luego, a la estrategia propagandística impulsada por Felipe V en 1709 que trataba de implicar al clero y a las universidades en la fundamentación de unos asuntos eclesiásticos hispanos que deseaba organizar a partir de entonces de manera independiente del Vicario de Cristo bajo la premisa de que su voluntad

\footnotetext{
65 Carta de fosé Molines firmada en Roma el 4 de octubre de 1709 (AHN, Estado, leg. 4813).

66 Pere MOLas RiBalTa, «Aragón» en el Consejo de Castilla, en Cuadernos dieciochistas, 2 (2001), p. 5.

67 Papel sobre puntos tocantes a la Junta formada para la salida del Nunpcio y declaración del Papa a favor del Archiduque (AMAEF, Mémoires et documents, Espagne, 249, fols. 334-335).

68 BNF, Manuscrits Occidentaux, Lorraine 856, fols. 165-166.
} 
se encontraba prisionera ${ }^{69}$; en este contexto, el Mariscal de Tessé -Embajador francés ante la Santa Sede-, en un escrito divulgado mediante su publicación en la imprenta madrileña de Antonio Bizarrón ${ }^{70}$, apelaba a que la Iglesia española debía actuar en conciencia buscando un camino acorde a lo estipulado desde antiguo mientras que el Santo Padre se liberaba de la esclavitud a la que estaba sometido:

(...) pero esta Iglesia no está más en Roma, mientras que Roma está dentro de la esclavitud; el Soberano Pontífice no puede estar ya en nuestro favor. Busquemos, pues, la seguridad de nuestras conciencias dentro de las reglas antiguas, supuesto que Roma ya no puede darlas, esperando que se digne el Rey de los Reyes, a bolvernos al Santo Pontífice libre, y a Roma independiente (...)

Precisamente, la recurrente mención al «Papa cautivo» por parte de los defensores de Felipe de Anjou tenía como principal objetivo denunciar públicamente ante los súbditos la nulidad jurídica del reconocimiento de Carlos de Austria como Rey de España basándose en el hecho, supuestamente confesado por el Obispo de Roma a los auditores de la Rota -según el informe de Francisco Portell-, de haberse efectuado con violencia y sin disponer de la libertad para pronunciarse sobre este asunto ${ }^{71}$; además, en el mencionado informe presentado por este miembro del Consejo de Castilla a la Junta competente para la salida del Nuncio se contempló como argumento de derecho con fines preventivos otorgarle igualmente la nulidad a cualquier censura, privación, pena o apremio que el Vicario de Cristo intentase promulgar o imponer posteriormente. En la línea de la invalidez de la declaración papal a favor del Archiduque se manifestaría también el Duque de Uceda cimentando su consideración en que suponía una injuria y una injusticia avalar a otro príncipe habiendo reconocido previamente a Felipe $\mathrm{V}$ después de haber tomado posesión de los territorios de la Monarquía Hispánica ${ }^{72}$.

69 En estos términos se reseñaba en la carta que Felipe $\mathrm{V}$ envió a los prelados, iglesias, universidades y religiones, cuya copia remitió la Nunciatura de España a la Santa Sede en 1709: «(...) En Italia y faltasse la liberttad y independenzia con la qual deven obrar los papas resistiendo la nezessidad y esttrechez y que combenía apelar de un papa cautivo a un papa puesto en liberttad» (ASV, Segr. Stato, Spagna, vol. 201, fols. 535-537).

70 Traducción de papel escrito por el Señor Mariscal de Tessé, a Su Santidad, el día 2 de enero de 1709 (ASV, Segr. Stato, Espagna, 201, fol. 219).

71 Papel sobre puntos tocantes a la Funta..., Documento citado.

72 DUQue De UCEDA, Protesta que el Duque (...), embaxador de España en Roma, hizo de la nulidad e injusticia en el reconocimiento del Papa al Archiduque Don Carlos por Rey de España (BNE, mss. 10712, fol. 313). 
Si los partidarios de Felipe de Anjou entendían que la cuestión de la proclamación del Rey de España no competía a Su Santidad, el paso publicitario inmediato les llevaba a declarar que esta potestad era exclusiva de los reinos con el fin de dejar claro que el monarca al que defendían había accedido legítimamente al Trono de España. Este razonamiento sería respaldado, entre otros, por Melchor Rafael de Macanaz ${ }^{73}$, y difundido entre los hispanos a través de diversos folletos impresos como el titulado Desengaño Cathólico; ciertamente, el autor de este último afirmaba la incapacidad del Emperador o del Santo Padre para dilucidar un reconocimiento que solamente correspondía -en su opinión- a los reinos y a los miembros de la Monarquía:

Pero demos, que tenga alguna probabilidad el derecho, que pretende a esta Corona el señor Archiduque, en contraposición de el que assiste al Señor Phelipe V (...), buelvo a preguntar, quién debe ser el Juez de ella? El Sumo Pontífice? No; porque esta materia es puramente temporal, y el Sumo Pontífice, según el mejor sentir, solo tiene jurisdicción en lo temporal indirectamente, y respectivamente a lo espiritual. El Emperador de Constantinopla, u otro algún Monarca temporal? Tampoco; porque a ninguno reconoce España por Superior (...), luego solo puede ser legítimo Juez de ella los Reynos, y miembros, que componen la Monarquía (... ${ }^{74}$.

En cualquier caso, el reconocimiento del Archiduque como Rey favorecía en gran medida los mensajes religiosos persuasivos divulgados por los agentes propagandísticos austracistas; no en vano, en el transcurso de 1709 se editaron numerosos folletos con la finalidad de ofrecer soporte publicitario a esta decisión de la Santa Sede ${ }^{75}$. A ello se sumaba la prensa oficial de la Corte establecida en Cataluña que a partir de ese año expandía las noticias de cada acontecimiento relacionado con este asunto; a modo de muestra, la Gaceta de Barcelona publicaba en marzo de 1711 la admisión solemne del Príncipe de Avellino como Embajador de Carlos de Austria ante el Pontífice Romano ${ }^{76}$. Desde luego, el recurso a utilizar los periódicos para exaltar la figura del príncipe austriaco no era una novedad, puesto que se aprecia en ejemplares de años anteriores e, incluso, en estrategias divulgativas previas adjudicadas, incluso, a miembros significados del estamento eclesiástico. A este respecto, el Duque de Uceda -Embajador de Felipe V- se refería a una actividad editorial de este tipo promovida en 1706

\footnotetext{
73 Melchor Rafael MACANAZ, Refutación erudita y satírica del papel que dio a luz E.P.D.Y.D.F sobre aclarar el lexítimo derecho que S.M. el Señor Don Phelipe $5^{\circ}$ tiene a la Corona de España, contra el pretendido por el Archiduque de Austria (BNE, mss. 10600, fols. 65-66).

74 D.J.D.F., Desengaño Cathólico, Sevilla, Imp. Juan de la Puerta, n.d., p. 6.

75 Rosa María Alabrús IgLesias, Felip V..., p. 211.

76 Gazeta de Barcelona, publicada a 28 de marzo de 1711 (ASV, Segr. Stato, Spagna, vol. 204A, fol. 199).
} 
por el Cardenal Grimani -defensor de los intereses austriacos y con cierta fama entre los felipistas de autorizar la publicación de libelos ${ }^{77}-$ :

También se ha sabido que el Cardenal Grimani secretamente ha hecho estampar una gazeta suponiéndola de Barzelona con aclamaziones al Archiduque en muchas partes de España, y en Madrid donde supone llegaron los portugueses la víspera de San Juan... ${ }^{78}$.

En esta campaña de difusión de la aceptación del príncipe Carlos como monarca de España tendría relevancia el hecho -si atendemos a la preocupación manifestada por el auditor Molines- de que los cardenales parciales al Archiduque lo denominaran Rey Católico de manera pública al mismo tiempo que lo intitulaban con este calificativo unos «papeles» estampados en Roma en torno al mes de abril de $1709^{79}$. A estas manifestaciones propagandísticas se unía el conjunto de celebraciones organizadas en Roma por el Marqués de Prié -Embajador Cesáreo-, preparadas con el objetivo de extender y hacer partícipes, a todos los residentes en la ciudad, del júbilo de los austracistas por el beneplácito otorgado a Carlos de Austria por parte del Papado. De este modo, la escenificación y reafirmación pública de la condición regia reconocida al Archiduque se teatralizó en el mes de septiembre de este año con un gran convite acompañado de música interpretada por trompetas y diversos instrumentos, la exposición de «infinidad de retratos» de Carlos III $^{80}$ y los numerosos vítores ${ }^{81}$ con que la multitud de sus partidarios aclamaban al nuevo Rey en la Plaza de España en Roma ${ }^{82}$. Casi dos meses después, el 4 de noviembre de 1709, siguiendo con la estrategia de promocionar la imagen del titular de la dinastía austriaca se promovió un nuevo evento festivo

77 Margarita MarTíN VelasCO, La documentación histórica y la publicística del siglo XVIII. Una insólita defensa de Felipe V: la respuesta del Duque de Uceda a un pasquín austracista difundido con motivo de la caída del reino de Nápoles en 1707, en Documentación de las Ciencias de la Información, 31 (2008), p. 206.

78 Carta al Gobernador de Milán, 17 de julio de 1706 (BNF, Manuscrits Occidentaux, Lorraine, 856, fol. 308).

79 Carta de fosé Molines dirigida a Félix de la Cruz Haedo el 7 de abril de 1709 (AHN, Estado, leg. 4813).

80 En el Diario di Roma se constata la venta pública del retrato de Carlos III en esta ciudad el 15 de octubre de 1709; es decir, un día después de la celebración de un consistorio en el que participaron 18 cardenales para tratar el efecto del reconocimiento como monarca del Archiduque de Austria: $\ll \mathrm{Si}$ portarono hoggi a venderé públicamente per la cittá gli ritratti del re Carlo III». Por otra parte, la imagen del rey de la dinastía austriaca se expuso con evidente intención propagandística en la Iglesia de San Carlo al Corso durante el mes de noviembre. Francesco VALESIO, pp. 350-351, 355 y 379.

81 El recurso propagandístico de las aclamaciones fue empleado con frecuencia por los austracistas y proborbónicos en la ciudad de Roma hasta el punto que se cruzaban los vivas a Carlos III con los destinados a Felipe V. Gianvincenzo GravinA, Curia romana..., pp. 333-334.

82 Misiva del clérigo Pedro Aguado enviada a Félix de la Cruz Haedo con fecha de 19 de septiembre de 1709 (AHN, Estado, legajo 4813). 
con ocasión de su onomástica y cumpleaños consistente en luminarias, fuegos artificiales, distribución de vino a los asistentes, y una cantata a tres voces alusiva a la gloria y virtudes del Rey ${ }^{83}$. Desde luego, este conjunto de recursos publicitarios no hacían más que dar fe, una vez más, de la instrumentalización propagandística de las decisiones y gestos del Pontífice y de la curia romana.

\section{LA RESPUESTA REPRESIVA DE FELIPE V: UNA ACTITUD ARRIESGADA EN EL DISEÑO PUBLICITARIO}

Sin duda, en este combate propagandístico por la legitimidad ante la opinión pública, la resolución de Clemente XI de aceptar los derechos dinásticos de Carlos de Austria, incentivó a Felipe $\mathrm{V}$ a mostrar su disconformidad con la actitud de la Santa Sede de inmiscuirse en asuntos temporales de manera que adoptó diversas represalias encaminadas a exhibir el poder del monarca sobre el intervencionismo eclesiástico en el ámbito político, aunque éstas supusieran tener que asumir los riesgos correspondientes a una opinión pública de confesión católica; en este marco se efectuó una ruptura con el Papado ${ }^{84}$, se expulsó al Nuncio de Madrid, se prohibió enviar dinero a Roma, se cerró el Tribunal de la Nunciatura, se retiró al Embajador, y se ordenó abandonar los Estados Pontificios a los naturales de España, entre otras medidas. De este modo se confirmaba el valor de unas palabras premonitorias escritas en el siglo XVI por Luis de Molina, conocedor de los entresijos de las relaciones entre la Iglesia y el poder de las dinastías católicas europeas, sobre lo que podría acontecer en el caso de que el Santo Padre interviniese en un litigio entre príncipes cristianos tal como el que tuvo lugar a principios del Setecientos; en efecto, las consecuencias que podía generar el reconocimiento de Carlos de Austria como rey de España se ajustó, en esencia, al clarificador juicio del mencionado sacerdote de la Compañía de Jesús que lo expresaba del siguiente modo:

... cuando la controversia tiene lugar entre Príncipes cristianos y se juzgase convenir absolutamente al bien de la Iglesia y al fin sobrenatural que el Sumo Pontífice la decidiese, podría éste entrometerse en ella por la plenitud de la potestad que tiene ordenada a dicho fin sobrenatural, avocando a si la causa, definiéndola por sentencia (...), ordinariamente será más conveniente que no lo haga porque ello podría dar

83 AEESS, vol. 365, fols. 299-304.

84 Bando publicado en Madrid el 30 de octubre de 1709 sobre el comercio con la Corte de Roma (AEESS, vol. 238, fol. 99). Santos M. CORONAS GONZÁLEZ (ed.), El Libro de las leyes del siglo XVIII. Colección de impresos legales y otros papeles del Consejo de Castilla (1708-1781), vol. I., BOE y Centro de Estudios Constitucionales, Madrid, 1996, p. 19. 
ocasión a gravísimos males, ya que el perjudicado fácilmente se encendería en odio hacia el Sumo Pontífice, creyéndolo movido por la pasión o por no haber estudiado bien el asunto al dar sentencia contra él, tomando de aquí ocasión para negar obediencia al Papa en otras cuestiones o incluso en el mismo litigio $(. . .)^{85}$.

En cualquier caso, esta actitud de castigo y de venganza decidida por Felipe de Anjou sobre el Nuncio y el Vicario de Cristo asumía sus riesgos ante la mentalidad católica hispana; no en vano, estas medidas suponían una afrenta a la máxima autoridad espiritual de la Iglesia y, por tanto, no gozaban de la simpatía popular, especialmente entre los miembros del clero español. De ello sería un ejemplo evidente las muestras de respeto y afecto recibidas por el nuncio Antonio Félix Zondadari en las poblaciones por las que transcurrió su itinerario de viaje para salir de España; en concreto, en el camino de la expulsión hacia la frontera francesa encontró el apoyo de cabildos eclesiásticos, superiores de órdenes religiosas, diputados de las ciudades, algunos catedráticos, entre otras personas ${ }^{86}$. Ni siquiera la Junta integrada por ministros de estado, miembros de los consejos y teólogos, formada con el objetivo de respaldar ante los súbditos las represalias mediante un dictamen moral, logró evitar el cuestionamiento de éstas por parte de figuras tan significadas como el Obispo Belluga o el Arzobispo de Santiago de Compostela; este último, en un escrito dirigido al Marqués de la Mejorada -Secretario del Despacho Universal-, instaba a Felipe $\mathrm{V}$ a no seguir la costumbre de los reyes que -según él- se rodeaban de teólogos y confesores que les decían lo que deseaban escuchar y no lo que Dios les dictaba ${ }^{87}$. Precisamente, entre los clérigos que participaron en la justificación teológica se encontraban Fray Alonso Pimentel y Fray Francisco Blanco, quienes ofrecieron soporte al discurso publicitario de la Corona de expulsar al Nuncio por tratarse exclusivamente -según sus informes- de un embajador que ejercía funciones diplomáticas en representación del Pontífice por su condición de príncipe temporal; de opinión semejante era el confesor real, pues afirmaba ser partidario de hacer pública repulsa de la «injuria» del reconocimiento a Carlos de Austria, aunque demostrando cierta prudencia en la ejecución de esta orden recomendaba que se tratara al Nuncio con respeto, atención y «reverencia debida a su

85 Luis de Molina, De bello; en Manuel Fraga Iribarne, Luis de Molina y el derecho de guerra, Instituto Francisco de Vitoria-CSIC, Madrid, 1947, p. 314.

86 Justo FERNÁNDEZ AlOnso, Un periodo de las relaciones entre Felipe V y la Santa Sede (1709-1717). Sus repercusiones de la «nación» española de Roma, en Anthologica Annua, 3 (1955), pp. 17-19.

87 Fray ANTONio MonRroy, Escripto al Marqués de la Mexorada, secretario del Despacho universal y del Patronato en respuesta de los manifiestos publicados contra el Papa en nombre de S.M. el año de 1709 (ARChIVo General de la NACIÓN, México [AGNM], Fondo Inquisición, vol. 715, exp. 11, fol, 382). 
representación ${ }^{88}$. Una vez estructurado el lenguaje de cariz represivo contra la Santa Sede, con la correspondiente colaboración de los eclesiásticos mencionados, las manifestaciones de otros clérigos que defendían la obediencia al Papa desde los púlpitos, solían ser castigadas con penas de prisión bajo la acusación de desafección; de ello dejaba un testimonio expresivo Fray Juan de San Antonio -predicador general de la orden jerónima-, quien debió tomar el camino del exilio tras haber pronunciado un sermón defendiendo la observancia de los decretos pontificios y después de saber que iba a ser prendido por este motivo ${ }^{89}$.

Después de que la Administración Borbónica había promovido la desobediencia al Santo Padre, mostraba con indiscutible habilidad entre los súbditos hispanos la adhesión a su figura espiritual ordenando a los obispos el 28 de junio de 1709 que efectuasen rogativas públicas y generales pidiendo a la Divinidad que lo sacase de la opresión a la que estaba sometido por las armas imperiales ${ }^{90}$. Ciertamente, mientras que Felipe $\mathrm{V}$ alentaba las predicaciones en contra de los mandatos pontificios con las consiguientes «irreverencias» hacia lo que representaba moralmente el Obispo de Roma -según expresaba un documento de la Nunciatura-, al mismo tiempo intentaba presentarse ante el pueblo español mediante las citadas rogativas como el garante de la libertad y el honor del denominado «Padre Común» de los príncipes católicos. En todo caso, una cuestión era el discurso propagandístico que pretendía divulgar entre sus vasallos y otra el hecho de que hubiera convencido a la jerarquía eclesiástica de que realmente había demostrado lealtad a la Silla Apostólica. En este sentido, si analizamos los escritos redactados por algunos prelados hispanos y los documentos que circulaban entre la Nunciatura y la Secretaría de Estado de la Santa Sede es evidente que la élite clerical atestiguaba que el Borbón permitía conductas irrespetuosas y discursos pronunciados en las iglesias contra el Papado; sirva como ejemplo de ello el documento enviado desde España por Guidobaldo Salamani a la sede central de la diplomacia pontificia el 13 de mayo de $1709^{91}$ :

... los oradores evangélicos (...) desde aquel alto puesto se oien disparadas, no solo irreverentes mormuraziones, y dicterios intolerables contra el Papa, sino también desfachadas blasfemias (...) querrá entibiar el amor al Papa entre una gente tan cathólica (...).

88 Consulta del Consejo de Estado, 22 de marzo de 1709, Madrid (AMAEF, Mémoires et documents, Espagne, 249, fols. 138-139 y 142).

89 Carta enviada por el Nuncio de España en Aviñón al Cardenal Paulucci (ASV, Segr. Stato, Spagna, 202, fols. 36-40).

90 ASV, Segr. Stato, Spagna, 201, fol. 496.

91 ASV, Segr. Stato, Spagna, 201, fols. 353-364. 
Desde luego, el comportamiento permisivo y condescendiente de Felipe de Anjou respecto a las críticas con fines publicitarios realizadas al sucesor de San Pedro sería reconocido indirectamente por el propio monarca en 1717; no en vano, hasta el cuatro de agosto de ese mismo año, una vez aprobado el Concordato con la Santa $S_{e d e}{ }^{92}$, no dictaba una orden señalando penas rigurosas para quienes manifestasen expresiones injuriosas condenadas por Su Santidad en el breve que había expedido en el mes de octubre de 1709, las cuales fueron calificadas por el mismo Felipe de Anjou -ocho años después de que las hubiera tolerado- como perniciosas y escandalosas «a los oídos de los fieles» ${ }^{93}$.

\section{A MODO DE CONCLUSIÓN}

Las relaciones entre el Papado y las dos dinastías que competían por la Corona de España estuvieron plagadas de paradojas y de discursos contradictorios en función de la evolución de los acontecimientos militares y diplomáticos que acontecían en el campo de operaciones y en los propios Estados Pontificios; hasta tal punto fue así que Clemente XI pasó de aceptar públicamente el statu quo de Felipe de Anjou como monarca otorgándole herramientas publicitarias para consolidar su imagen entre los hispanos hasta evolucionar hacia el reconocimiento de Carlos de Austria como Rey de «las Españas» censurando las críticas que le dirigían el Borbón y sus partidarios. De este modo, en el marco de una estrategia propagandística interesada en difundir el conflicto sucesorio como una «guerra de religión» los candidatos al trono, a pesar de su condición de príncipes católicos, adoptaron conductas opresivas e irrespetuosas con el Santo Padre, lo que les obligó a diseñar discursos que fueran lo suficientemente hábiles y verosímiles para justificar estos comportamientos de manera que no generasen la desafección de los súbditos hispanos, a quienes lógicamente desorientaría y les resultaría complejo comprender que gobernantes que afirmaban defender la fe católica no tuvieran reparos, al mismo tiempo, en pronunciarse contra la obediencia al Vicario de Cristo e, incluso, como sucedió con Felipe V, que diese órdenes para la expulsión del Nuncio o para romper las relaciones con la Santa Sede con el riesgo cismático que suponía que la Corona pudiese nombrar prelados y cargos eclesiásticos que no eran reconocidos por el sucesor de San Pedro.

\footnotetext{
92 Clemente XI ratificó este concordato mediante un breve con fecha de 10 de julio de 1717. Maximiliano Barrio GOZALO, El cardenal Alberoni y España. Política religiosa y carrera eclesiástica, en Hispania Sacra, 63, 127 (2011), p. 219.

93 ASV, Segr. Stato, Spagna, App. XIII.
} 
En este contexto la ciudad de Roma fue un escenario fundamental en la campaña publicitaria impulsada para la justificación de los derechos dinásticos de Carlos de Austria y de Felipe de Anjou; por ello, Clemente XI y el Sacro Colegio Cardenalicio fueron objetivos relevantes de la propaganda política con el ánimo de influir en el posicionamiento de éstos respecto a los candidatos al Trono de España, de tal modo era así que los propios autores de los impresos reconocían el empleo de la estrategia de divulgar informaciones satisfactorias para el príncipe al que servían como instrumento para modificar o, en su caso, incentivar la toma de decisiones por parte del Papado. De igual forma, las fuentes documentales investigadas demuestran que la capital de los Estados Pontificios fue un espacio nuclear que actuaba de centro de difusión de noticias y mensajes en toda Italia, en los estados extranjeros y en los diversos reinos de la Monarquía Hispánica como resultado de su condición de lugar de encuentro y de conexión de la diplomacia internacional, así como consecuencia de haber sido un cualificado centro neurálgico de las comunicaciones que llegaban a los clérigos seculares y regulares que residían en los diferentes territorios del Imperio Español; de ahí que la ciudad eterna fuera durante la Guerra de Sucesión un altavoz destacado de efectos multiplicadores de todas las noticias y versiones contradictorias referentes a la crisis sucesoria y a los sucesos militares acaecidos entre las potencias europeas. En este sentido, ni siquiera el carácter eclesiástico de la Santa Sede evitó que hubiese eclesiásticos partidarios de uno u otro pretendiente a la Corona de España que de manera reiterada distribuyeran falsas informaciones desde el centro de la Cristiandad, aunque insertas en lo que hemos denominado «publicística de la verosimilitud», generando confusión entre los diplomáticos y entre la población receptora de los mensajes.

Por otra parte, también resulta evidente que la celebración de festejos y de ceremonias para ensalzar y difundir los triunfos políticos o militares de las dos dinastías enfrentadas se constituyó en una forma de lenguaje expresivo de la contienda sucesoria en el ámbito público con la intencionalidad de implicar a los diferentes diplomáticos y políticos instalados en Roma con una de las dos candidaturas; en este sentido, las invitaciones a los representantes de otros estados a las fiestas organizadas por los partidarios de Felipe de Anjou o de Carlos de Austria formaban parte de una táctica sutil dirigida a combatir cualquier posición de neutralidad y, por supuesto, un modo de escenificar las lealtades, aunque fuesen forzadas, con la finalidad de mostrarlas como ejemplo y referentes que animasen a otros a unirse a la defensa de sus respectivas causas. Desde luego, este conjunto de actividades lúdico-festivas de perfil propagandístico (musicales, teatrales, luminarias, fuegos de artificio, ceremonias religiosas, entre otras) posibilitaron que Roma se convirtiese, como se ha indicado previamente, en un espejo de las osci- 
laciones de los apoyos internacionales a los Austrias y a los Borbones, de manera que permitían pulsar la posición de los diplomáticos y agentes de las potencias implicadas en el conflicto bélico.

Precisamente en este marco los contendientes en la Guerra de Sucesión española vigilaban con detalle cualquier ceremonia o gesto del Sumo Pontífice por si pudieran significar un respaldo a uno de los dos aspirantes al Trono de España; no en vano, como se ha podido comprobar, solían tener un efecto publicitario relevante en el discurso de aparente neutralidad que se trataba de transmitir desde la Santa Sede, pero que en determinadas ocasiones mostró paradójicamente una notable complicidad con Felipe $\mathrm{V}$ a comienzos de su reinado y, posteriormente, con el Archiduque tras reconocerlo como Rey. A este respecto debe recordarse la repercusión que originaba la formalización o no de determinados actos simbólicos en el debate sobre la legitimidad de los pretendientes a la Corona, en las actitudes de rebeldía o de desafección de los súbditos hispanos o, en su caso, en la aceptación por éstos del príncipe señalado favorablemente por el protocolo de la Santa Sede; valga como ejemplo la resistencia a la ejecución de la investidura del reino de Nápoles mediante la Accanea o, por contra, la difusión de la carta de Clemente XI asumiendo la condición de monarca de Felipe de Anjou, entre otras manifestaciones.

Con todo, Albani, a pesar de haber tratado de aparentar la equidistancia calculada con ambos príncipes cristianos tras romper con su actitud ambigua de manera forzada como consecuencia de la presión de las fuerzas armadas del Imperio austriaco, acabó siendo objeto de una campaña de desprestigio ante la opinión pública auspiciada por Felipe V a partir de 1709, pero que como se ha podido observar había comenzado a forjarse con ciertos antecedentes a partir de 1705 desde la Embajada de España en Roma, de modo que finalmente apareció retratado y divulgado por los publicistas como un «Papa esclavo» o un «Papa cautivo» con el fin de limitar el incuestionable impacto que el reconocimiento de Carlos de Austria podía generar en la mentalidad católica de los españoles.

En cualquier caso, a pesar de las medidas represivas de connotaciones publicitarias adoptadas por la Administración Borbónica tales como la expulsión del Nuncio y la ruptura del «comercio» con Roma, y tras haber promovido la desobediencia al Vicario de Cristo, Felipe V demostró disponer de la suficiente habilidad propagandística para presentarse ante los súbditos hispanos mediante rogativas públicas y otras formas de expresión como el garante de la libertad del Pontífice Romano, si bien esta estrategia de comunicación social no convenció a los miembros de la jerarquía eclesiástica que habían demostrado lealtad a la Santa Sede ante ese tipo de comportamientos irrespetuosos con el máximo representante de la Iglesia Católica. 